\title{
Keterdidikan Perempuan dan Wacana Kesetaraan dalam Novel Indonesia Pra-Balai Pustaka
}

\author{
Yulianeta \\ Universitas Pendidikan Indonesia \\ yaneta@upi.edu
}

\begin{abstract}
How to cite (in APA Style): Yulianeta. (2018). Keterdidikan perempuan dan wacana kesetaraan dalam novel Indonesia pra-Balai Pustaka. Jurnal Pendidikan Bahasa dan Sastra, 18(1), 81-94, doi: 10.17509/bs_jpbsp.v18i1.12148.
\end{abstract}

Article History: Received (December 14, 2017); Revised (February 5, 2018); Accepted (March 22, 2018).

Journal homepage: http://ejournal.upi.edu./index.php/BS_JPBSP

\begin{abstract}
Abstrak: Penelitian ini berpijak pada fenomena bahwa karya sastra tidak lahir dari kekosongan budaya dan kekosongan sosial. Novel-novel Indonesiapra-Balai Pustaka menandai kesadaran masyarakat terhadap pentingnya keterdidikan sehingga tidak lepas dari sistem sosial budayanya. Isu pentingnya keterdidikan perempuandan wacana kesetaraan telah terbentang dalam novel-novel Indonesia pra-Balai Pustaka. Hal ini penting untuk direfleksikan sebagai upaya memperkaya khazanah kesusastraan Indonesia yang acapkali menganaktirikan karya sastra pra-Balai Pustaka. Tiga novel Indonesia pra-Balai Pustaka yang mengangkat isu keterdidikan perempuan dan wacana kesetaraan menunjukkan kepedulian para pengarang Indonesia terhadap permasalahan yang berhubungan dengan pendidikan perempuan. Penelitian ini berupaya menggali wacana kesetaraan dalam tiga novelIndonesia pra-Balai Pustaka yang terkubur dalam perjalanan kesusastraan Indonesia. Untuk itu digunakan kritik sastra feminis dan perspektif gender. Hasil penelitian ini memberikan kontribusi untuk dunia kesusastraan Indonesia, khususnya aktivitas kritik sastra Indonesia yang merefleksikan kehadiran novel-novel Indonesia pra-Balai Pustaka untuk pengembangan kritik sastra di masa kini dan nanti.
\end{abstract}

Kata kunci: keterdidikan perempuan, wacana kesetaraan, novel Indonesia pra-Balai Pustaka

\section{Women's Education and Equality Discourse in The Pre-Balai Pustaka Indonesian Novels}

\begin{abstract}
This research based on the phenomenon that literary works are not born from cultural vacuum and social emptiness. The pre-Balai Pustaka Indonesian novels mark the social understanding on the major position of education within social cultural system. The issue of women's education and equality has been spawned throughout pre-Balai Pustaka Indonesian novels. This is compellingly important to explore as an effort to enrich the literary treasures of Indonesia since this pre-Balai Pustaka literary works is often overlooked. Three pre-Balai Pustaka Indonesia novels that raise issues of women's education and equality uncover its author concern on women's education issues. Therefore, this research seeks to explore the discourse of women equality and education in three pre-Balai Pustaka Indonesian novels using feminist literary criticism and gender perspective. These three novels have been overlooked in the discourse of Indonesian literature. The results of this study contribute to the activities of world Indonesian literary criticism that may reflect the representation of pre-Balai Pustaka Indonesia novels within the development of current literary criticism.
\end{abstract}

Keywords: women's education, equality discourse, pre-Balai Pustaka Indonesia novels 


\section{PENDAHULUAN}

Pada masa kolonial, perempuan dicitrakan sebagai sosok manusia yang terpinggirkan. Kaum perempuan yang berasal dari lapisan terbawah dijadikan budak yang tidak bisa bernegosiasi atau mengajukan tuntutan apapun (Hellwig, 2007,p. 36). Hasrat penjajah telah mengubur hak-haknya untuk menjadi perempuan terdidik, padahal sebuah bangsa harus melahirkan seorang perempuan tulen, kuat, dan dapat mengendalikan dirinya(Gandhi, 2002,p. 3).

Persoalan tersebut juga ditandai oleh keterbatasan ruang gerak perempuan dalam konstruksi sosial sehingga pendidikan menjadi impian yang langka untuk diwujudkan (Saputra, 2011) dalam Ridwan, et al., 2016,p. 71). Fenomena ini menunjukkan bahwa keterdidikan perempuan dan wacana kesetaraan menjadi isu penting dalam pembangunan. Kesetaraan ini pula yang tampak alfa dari prioritas pembangunan bangsa kita di era global sehingga indeks pembangunan manusia (IPM) Indonesia turun dari peringkat ke-110 menjadi peringkat ke113 pada tahun 2016 (Kompas, 1/6).

Isu keterdidikan perempuan dan wacana kesetaraan menjadi salah satu topik yang menantang untuk direfleksikan, terutama dalam dunia sastra Indonesia. Berpijak pada perjalanan sejarah dan kesusastraan nasional, isu tersebut menarik ditinjau dalam novelnovel Indonesia pra-Balai Pustaka sebagai khazanah penting sebelum Balai Pustaka menyensor sedemikian rupa konsumsi bacaan masyarakat.

Pemerintah Belanda pada masa itu membatasi ruang gerak rakyat, tidak terkecuali aktivitas membaca buku-buku sastra. Pelarangan tersebut terwujud dengan didirikannya lembaga sensor, Balai Pustaka (1908 - 1942). Lembaga ini melakukan kontrol sosial dan politik terhadap bacaan-bacaan liar (teks bacaan yang diterbitkan oleh komunitas Tionghoa, Arab, dan Pribumi) di Indonesia. Kontrol sosial dan politik tersebut dilakukan dalam upaya mengeksistensikan dirinya sebagai penjajah yang menaklukkan pribumi seutuhnya. Oleh karena itu, semua bacaan yang diterbitkan ada dalam pengawasan dan sensor kekuasaannya (Yasa, 2013,p. 250).

Kartikasari (2014) mengatakan bahwa bacaan liar di zaman kolonial Belanda merupakan bacaan yang dilarang beredar di masyarakat Hindia karena isinya cenderung menentang kekuasaan pemerintah Belanda. Bacaan-bacaan tersebut juga dipersepsi sebagai upaya pergerakan masyarakat agar terbebas dari tangan kekuasaan pemerintah. $\mathrm{Hal}$ inilah yang membuat Belanda menghambat perkembangannya dengan cara mendirikan Balai Pustaka dan memenjarakan pengarang yang mengkritik pemerintah.

Beberapa bacaan liar yang dilarang beredar pada masa tersebut adalah novel Student Hidjo (1919) dan Rasa Merdika (1924) karya Mas Marco Kartodikromo, serta Hikayat Kadiroen (1924) karya Semaoen.Ketiga novel tersebut pada awalnya merupakan cerita bersambung yang dimuat dalam surat kabar Sinar Hindia (Domono, 2013: 30).Kedua pengarang novel yang dianggap melahirkan bacaan liar ini (novel propaganda politik dalam istilah Yulianeta, 2008) merupakan sosok penting pada zaman pergerakan. Keduanya mengusung semangat yang sama untuk membangun wacana kesetaraan sebagai upaya menggugah kesadaran masyarakat pribumi yang terpecah belah di Hindia Belanda.

Melalui novel yang ditulisnya, Mas Marco Kartodikromo sebagai seorang aktivis Sarekat Islam menghadirkan tokoh Hidjo yang berasal dari kaum menengah ke bawah (seorang pedagang). Sosok lelaki itu diciptakan untuk mengusung semangat pemuda yang berjiwa kritis dan cerdas dalam memaknai perbedaan kelas pada struktur sosial bangsanya (Hindia Belanda). Hidjo melanjutkan studinya di Belanda. Di sanalah konflik-konflik internal dan eksternal terjadi dalam kehidupannya selain kabar-kabar dilematis dari tanah kelahirannya.

Setelah Mas Marco hijrah menuju gerakan komunisme, ia melahirkan novel Rasa Merdika (1924). Dalam novel itu, ia tetap menggunakan idealisme seorang pemuda dalam mengkritik ketidakadilan yang terjadi 
pada kaum lemah seperti buruh tani. Sosok Soedjanmo yang berasal dari keturunan borjuis kecil (bernaung dalam tatanan pemerintahan) dicitrakan mampu mengenyam dunia pendidikan. Akan tetapi, Soedjanmo diarahkan ayahnya untuk bekerja pada pemerintah Hindia Belanda seperti yang terjadi pada dirinya dan saudara-saudaranya.

Mas Marcomenghadirkan kebobrokan penjajah melalui kritik tokohnya atas ketidakberesan yang terjadi. Sosok Ayah, baik dalam Student Hidjo dan Rasa Merdika mengasosiasikan bahwa berada pada wilayah pemerintahan akan mempertinggi derajat sosialnya di masyarakat. Hal inilah yang memicu kemajuan pikiran tokoh Hidjo dan Soedjanmo dalam kedua novel tersebut. Seperti halnya Mas Marco, Semaoen sebagai sosok penting partai komunis juga menghadirkan wacana kesetaraan melalui idealisme seorang pemuda bernama Kadiroen. Tokoh lelaki yang dicitrakan mengusung keadilan dan semangat kebangsaan untuk menyatukan masyarakat Indonesia. Salah satu jalannya adalah melalui edukasi kepada masyarakat luas dengan berbagai cara.

Atas dasar tersebut, ketiga novel yang menjadi bahan penelitian mereprentasikan keterdidikan perempuan dan wacana kesetaraan sebagai sarana memperjuangkan keadilan.Ketiga novel yang selama ini dianggap sebagai "bacaan liar" ini tidak selamanya berdampak negatif terhadap pengembangan budaya literasi Indonesia. Sangat disayangkan, jika kita menganaktirikan karya-karya cap "bacaan liar" tanpa melakukan penelitian yang mendalam terhadap karya tersebut. Dalam hal ini, upaya peningkatan itu dapat ditempuh melalui kritik atas karya-karya yang dihasilkan, membuat perspektif yang berbeda agar masyarakat dapat memahami hakikat persoalan sebenarnya. Dengan demikian, kekayaan estetika dalam novel-novel Indonesia praBalai Pustaka akan mampu berkontribusi terhadap perkembangan kesusastraan Indonesia masa kini guna memperkuat khazanah sastra Indonesia di masa depan.
Hal ini diperkuat dengan kehadiran berbagai penelitian sebelumnya yang relevan. Yulianeta (2008) meneliti cap "bacaan liar" pada novel propaganda politik (Student Hidjo, Hikayat Kadiroen, dan Rasa Merdika). Penelitiannya melihat bahwa ketiga karya tersebut menjadi bagian yang unik dalam sejarah perkembangan sastra Indonesia dan seyogianya tidak dianaktirikan sehingga layak untuk menjadi alternatif dalam pembelajaran sastradi sekolah. Asumsi tersebut juga tampak pada penelitian Mahayana (2010). Dalam penelitiannya, Mahayana mengkaii hubungan perempuan dan agama dalam novel Indonesia. Penelitiannya melihat adanya unsur perjuangan dari para tokoh perempuan yang terekam dalam novel Indonesia sebelum era kemerdekaan dan seusai kemerdekaan. Dari pengamatannya, masalah yang dianggap paling serius dihadapi perempuan Indonesia terjadi di kalangan masyarakat bawah. Mahayana belum melihat bahwa hal itu justru ada pada keterdidikan perempuan dan wacana kesetaraan (dalam arti semua pihak, baik itu laki-laki maupun perempuan; kaya maupun miskin) dapat mendapatkan hak yang sama dalam kehidupan berbangsa dan bernegara. Sementara itu, Saputra (2011,p. 136) mengatakan bahwa eksistensi sastra Indonesia terlalu cepat mengarah pada eksistensi Balai Pustaka (1917) -yang juga dikenal sebagai Kantor Bacaan Rakyat (Kantoor voor de Volkslectuur) setelah sebelumnya bernama Komisi Bacaan Rakyat (Commissie voor de Inlandsche School en Volkslectuur) 1908. Meskipun sebelum Azab dan Sengsara (1920) terdapat beberapa karya yang berkualitas dan menarik, misalnya karya-karya Mas Marco Kartodikromo dan Semaoen, Balai Pustaka tidak menerbitkannya.

Hal ini dikatakan Yasa dalam penelitiannya sebagai ketakutan pemerintah kolonial Belanda karena karya-karya Mas Marco (Mata Gelap, Student Hijo, Syair Rempahrempab, dan Rasa Merdeka) dan karya Semaoen (Hikayat Kadiroen) bernuansa kritik sosial sekaligus memiliki atmosfer untuk menginspirasi masyarakat (Yasa, 2013,p. 
250). Selanjutnya, dalam buku yang berjudul Menjadi Perempuan Terdidik: Novel Indonesia dan Feminisme, Wiyatmi (2013) mengungkapkan bahwa sejak perkembangan awal sastra Indonesia tahun 1920-an terdapat novel-novel yang kental mengangkat isu keterdidikan perempuan. Sayangnya, Wiyatmi baru melihat hal itu dalam novel-novel terbitan Balai Pustaka, seperti Azab dan Sengsara (1920) dan Siti Nurbaya (1922).

Seperti yang kita ketahui, novel-novel Balai Pustaka telah disensor sedemikian rupa. Artawan dan Yasa (2015) memperkuat hal tersebut melalui temuan mimikri dan stereotipe kolonial terhadap budak dalam novel-novel Balai Pustaka. Hal ini menunjukkan bahwa novel-novel terbitan Balai Pustaka tidak terlepas dari persoalan kepentingan pemerintah kolonial Belanda.

Dari berbagai penelitian sebelumnya, terlihat bahwa persoalan keterdidikan perempuan dan wacana kesetaraan belum dikaji secara utuh dan mendalam dalam novel-novel Indonesia pra-Balai Pustaka. Isu keterdidikan perempuan dan wacana kesetaraan belum dikaitkan secara tuntas sehingga penelitian ini dapat melengkapi penelitian sebelumnya. Hal ini senada dengan amanat Paus Sastra Indonesia, H.B. Jassin untuk tidak menafikan kesusastraan sebelum zaman Balai Pustaka karena berdampak pada penguburan suatu wadah dalam perjalanannya membentuk sejarah, penelitian ini memberikan perspektif yang berbeda sebagai upaya memperkuat khazanah kesusastraan Indonesia.

Untuk mengungkap keterdidikan perempuan dan wacana kesetaraan dalam novel-novel Indonesia pra-Balai Pustaka digunakan kritik sastra feminis dan perspektif gender. Keduanya berusaha memahami realitas dan konteks sosio-kultural yang terjadi dalam masyarakat yang mengandung diskriminasi, ketidakadilan, dan bahkan penindasan (Wiyatmi, 2013). Kritik sastra feminis berakar dari intuisi mendasar yang bersifat apriori bahwa kedudukan perempuan adalah kesadaran diri, bukan orang lain. Konsep apriori ini meliputi: (1) perempuan dalam sastra yang ditulis oleh penulis laki-laki sebagian besar dianggap sebagai objek; (2) asumsi utama seorang kritikus dalam citra perempuan harus mampu mengevaluasi keaslian karakter perempuan. Keaslian sebagaimana filsuf eksistensialis Heidegger merujuk pada kesadaran diri yang kritis, sebagai lawan dari stereotip (Endraswara, 2013,p. 151). Stereotip memberi arah perilaku bagi seseorang karena seringkali menentukan cara seseorang dalam memandang suatu kelompok maupun dalam berinteraksi dengan orang lain (Sadli dan Soemarti, 1995,p. 71-72).

Kedua konsep tersebut dibangun oleh pandangan-pandangan berdasarkan pengetahuan sosial dan kemanusiaan. Kritik ini berakar dari feminisme dengan pemahaman dasar mengenai seks dan gender. Seks secara permanen tidak berubah dan merupakan ketentuan biologis, sedangkan gender merupakan suatu sifat yang melekat kepada kaum laki-laki dan perempuan yang dikonstruksi secara sosial maupun kultural (Rutven, 1990,p. 24-48; Djajanegara, 2003).

Karya sastra (novel) menunjukkan posisi perempuan pada tempat yang lebih rendah dibandingkan laki-laki karena adanya patriarki yang memungkinkan laki-laki mendominasi perempuan pada semua hubungan sosial (Culler, 1983,p. 47; Rutven, 1990,p. 1). Kelahiran karya sastra tidak terlepas dari realitas dan fenomena sosial budaya, karena itu masalah keterdidikan perempuan dan wacana kesetaraan dalam novel-novel Indonesia pra-Balai Pustaka menunjukkan kepedulian para pengarang Indonesia terhadap masalah tersebut. Hal ini semakin tajam apabila dikaji menggunakan perspektif gender.

Udasmoro (2009,p. 1) menegaskan bahwa gender didefinisikan sebagai relasi sosial antara orientasi-orientasi seksual yang berbeda yang melibatkan konstruksi sosial, politik, dan kultural. Jadi, gender bukanlah kodrat, melainkan peran yang ditampilkan oleh budaya yang menempatkan perempuan dan laki-laki menjadi feminin atau maskulin. Perkembangan sejarah menunjukkan 
ketergantungan hidup perempuan pada lakilaki, di mana perempuan ditempatkan pada karakteristik yang dianggap khas perempuan. Hal inilah yang menimbulkan terbentuknya stereotip gender. Dengan mengangkat isu keterdidikan perempuan dan wacana kesetaraan, penelitian ini memberikan informasi tentang proses pelambangan (simbolisasi) dan pembentukan (konstruksi) perempuan secara mental melalui teks sastra (Suryakusuma, 1991).

Mengacu pada paparan di atas, penelitian ini berupaya menggali wacana kesetaraan dalam tiga novelIndonesia praBalai Pustaka yang terkubur dalam perjalanan kesusastraan Indonesia.

\section{METODE}

Penelitian ini menggunakan metode deskriptif kualitatif. Paradigma ini memberikan perhatian terhadap data alamiah, data dalam hubungannya dengan konteks keberadaannya. Cara-cara inilah yang mendorong metode deskriptif kualitatif dianggap sebagai multimetode sebab penelitian pada gilirannya melibatkan sejumlah besar gejala sosial yang relevan (Ratna, 2013).

Sementara itu objek penelitian ini adalah novel-novel Indonesia pra-Balai Pustaka, yakni novel Student Hidjo dan Rasa Merdika karya Mas Marco Kartodikromo, serta novel Hikayat Kadiroen karya Semaoen. Novel merupakan genre sastra yang sangat signifikan untuk memahami aspirasi pengarang dan secara kultural dapat mengidentifikasi budaya dan tradisi sastra (Anwar, 2009,p. 49). Sementara itu, Nurgiyantoro (2013,p. 11) mengatakan bahwa novel memiliki kelebihan dalam mengemukakan suatu persoalan kehidupan yang kompleks dan mengkreasikan dunia secara utuh.

Objek data yang berupa karya sastra (novel) tidak hanya dipandang sebagai bentuk substansif, melainkan makna-makna yang terkandung dibalik tindakan yang justru mendorong timbulnya gejala sosial tersebut.Sementara data formal dalam ketiga novel yang dikaji berupa kata-kata, kalimat, dan wacana menjadi perhatian yang penting.

\section{HASIL DAN PEMBAHASAN}

Novel Student Hidjo (1919), Hikayat Kadiroen (1922), dan Rasa Merdika (1924) terlahir pada zaman pergerakan ketika pemerintah kolonial Belanda berkuasa. Novel yang mengkritik kontradiksi kolonialisasi itu menjadi sastra pergerakan (dalam istilah Sapardi Djoko Damono, 2013) dari kaum pribumi atas kesewenang-wenangan penjajah. Sosok intelektual yang direpresentasikan pengarangnya membuat sastra menjadi alat menyuarakan persatuan dan kesatuan dalam masyarakat. Diramu dengan bahasa yang populer, ketiga novel yang dianggap remehtemeh itu (bahasa Melayu Pasar yang dipertentangkan dengan bahasa Melayu Tinggi) melambangkanperadaban yang berharga, terutama makna keterdidikan dan wacana kesetaraan.

Persoalan tersebut dilandasi ciri khas ideologi tertentu seperti komunisme yang muncul di tengah penguasa (Yulianeta, 2008; Damono, 2013).Ketiga novel itu dilandasi paham-paham tertentu, khususnya ideologi komunis. Pada dasarnya, ketiga novel tersebut menyuarakan persoalan keadilan dan nilainilai kemanusiaan yang berharga. Lokalitas primordial yang dimunculkan menambah daya tarik ketiga novel yang berlatar kebudayaan Jawa tersebut. Selain itu, wacana kesetaraan yang disuarakan menjadi titik tekan yang mengumandangkan kemanusiaan yang adil dan beradab. Hal itu direpresentasikan melalui kehadiran tokoh utama yang memiliki idealisme tinggi, kritis, dan peka terhadap keadaan bangsanya. Berikut ini akan dipaparkan keterdidikan perempuan dan wacana kesetaraan dalam ketiga novel yang menjadi objek penelitian.
1) Novel Student Hidjo (1919) karya Mas Marco Kartodikromo


Tidak kalah saing dengan Aqab dan Sengsara (1920) ataupun Siti Nurbaya (1922) terbitan Balai Pustaka, novel Student Hidjo mengisahkan persoalan cinta segi enam yang menarik antara orang Belanda yang mencintai orang Hindia seperti Walter kepada R.A. Woengoe, ataupun Betje kepada Hidjo; sesama orang pribumi yang berbeda kelas seperti perjodohan Hidjo dan R.A. Biroe, cinta Hidjo kepada R.A. Woengoe, dan cinta Wardojo kepada R.A. Biroe. Persoalan cinta itu ditempatkan dalam konteks yang tidak berlebihan, memperkuat pusat penceritaan agar orang Hindia mendapatkan pengakuan dan hak yang sama.

Pengarang memilih tokoh laki-laki sebagai tokoh utama, sedangkan tokoh perempuan dijadikan tokoh penunjang. Meskipun demikian, sosok Raden Ajeng Biroe dan Raden Ajeng Woengoe merepresentasikan perempuan Hindia yang terdidik karena berasal dari kalangan bangsawan. Dalam hal ini, pengarang turut mengkritik ketimpangan kelas dan jurang pemisah antargolongan pada masyarakat Hindia Belanda.

Pendidikan perempuan masih terbatas pada golongan tertentu sehingga kaum pribumi golongan bawah sangat langka mengaksesnya. Posisi ini jelas menempatkan perempuan sebagai objek keadaan karena persepsi perempuan hanyalah subordinat dari laki-laki. Pengarang menghadirkan aspirasiaspirasi perempuan melalui novelnya. Selain itu, kritik juga muncul dari kesadaran orang Belanda seperti Controleur Walter yang menyayangkan kesewang-wenangan bangsanya di Hindia. Anggapan masyarakat Hindia seperti budak (Slaafsch) dikritik Walter dan ia menyuarakan pentingnya pendidikan bagi masyarakat Hindia. Narasi itu tersurat ketika ia berdebat dengan Sersan Djepris, seorang kolonial yang digambarkan sebagai tokoh yang tidak berbudi.

Keterdidikan perempuan juga tampak pada sosok ibu yang mengkhawatirkan Hidjo ketika melanjutkan studinya di Belanda.
Ketakutan akan "pergaulan bebas" menunjukkan keterdidikan sosok Ibu memainkan posisi sebagai orang tua yang menginginkan hal terbaik bagi anaknya. Hal ini juga tampak pada kehadiran R.A. Biroe dan R.A. Woengoe yang secara fisik ditampilkan kecantikannya. Kedua perempuan yang berasal dari kaum terpandang ini menjadi relasi yang menarik dengan kehadiran Hidjo sebagai representasi kaum saudagar.

Kisah perjodohan menjadi penguat yang menarik untuk menyuarakan kesetaraan bahwa semua orang berhak memperoleh hak yang sama dalam kehidupan. Jurang perbedaan kelas dapat dijembatani dengan semangat keadilan dan kesetaraan agar tidak terjadi diskriminasi atau penindasan. Dalam hal ini, Mas Marco melalui Student Hidjo menunjukkan keberpihakannya kepada kaum Bumiputra secara lugas.

Hal tersebut tampak pada maksud ayah Hidjo, Raden Potronojo untuk menyekolahkan anaknya ke negeri Belanda. Ia menginginkan agar anaknya mampu mengangkat derajat keluarganya dalam kehidupan di Hindia. Gagasan tersebut dapat kita lihat pada kutipan berikut.

Saja ini seorang soedagar sadja, kamoe tahoe sendiri, ini waktoe orang seperti saja misih dipandang rendah oleh orangorang jang djadi penggawainja Gouvernement, kadangkadang kita poenja sanak sendiri jang sama toeroet Gouvernement dia tidak soeka koempoel dengan kita, sebab pikirannja dia orang ada lebih tinggi deradjatnja dari pada kita orang jang sama djadi soedagar atau tani. Maksoed saja boeat mengirimkan Hidjo ke negeri Belanda itoe tidak lain soepaja orang-orang jang merendahkan kita orang ini bisa mengerti, bahwa manoesia itoe sama sadja. Tandanja anak kita bisa beladjar djuga seperti anaknja Regentregent dan pangeran-pangeran (Kartodikromo, 1919,p. 6).

Kutipan tersebut menggambarkan pertentangan kelas antara saudagar dengan kaum priyayi. Meskipun sesama pribumi, 
politik etis pemerintah kolonial membuat masyarakat Hindia tercerai-berai karena golongan atas/borjuis menganggap rendah golongan bawah. Sang Ayah menyuarakan bahwa manusia itu tidak memandang kelas. Semuanya pantas mendapatkan hak-haknya. Oleh sebab itu, ia menyekolahkan Hidjo ke Belanda agar anaknya seperti pangeran ataupun anak petinggi pemerintahan.

Hal ini diperkuat oleh pendapat Siregar (1964) (dalam Yulianeta, 2008) yang menyatakan bahwa Mas Marco Kartodikromo adalah pengarang yang pertama kali melancarkan kritik terhadap feodalisme dan kolonialisme atas dasar perjuangan kelas. Student Hidjo merupakan novel yang berisi kritikan terhadap pemerintah Belanda. Dalam novel ini ditunjukkan kebejadan moral dari tokoh-tokoh Belanda, seperti Bejte yang hampir menjerumuskan Hidjo dalam kehidupan yang kurang baik.

\section{Pendidikan Hidjo di Belanda mampu} membuka nuraninya tentang narasi kebangsaan. Hidjo mendapat perlakuan yang kurang menyenangkan di negeri yang menjajah tanah kelahirannya itu. Ia mendapat julukan "pendito" hingga persepsi "banci" karena seorang pemuda yang suka sekali belajar, tidak banyak bicara, dan tidak senang berfoya-foya. Ia pun terlibat hubungan asusila di luar nikah dengan Betje, putri directeur salah satu maatschapij yang rumahnya ditumpangi Hidjo selama studi di Belanda.

Peristiwa ini tidak terlepas dari gaya hidup modern yang dilakoni Hidjo, seperti berbicara dengan bahasa Belanda, berpakaian model Barat, menonton film, menikmat musik, ataupun minum limun. Pengalaman Hidjo di Negeri Belanda mengajarkan dirinya bahwa bangsa Belanda ternyata tidak "setinggi" yang ia bayangkan (Yulianeta, 2008). Hidjo dapat memerintah orang-orang Belanda yang bekerja di hotel, restoran, atau di rumah tumpangan. Tindakan yang amat mustahil jika dilakukan di Hindia sebagaimana tergambar dalam kutipan berikut.
Waktoe itoe Hidjo toeroen dari kapal, dipelaboehan soedah berdesak-desakan orang-orang jang sama meraetoek sanak familienja jang datang dengan kapal Goerioeng. Keadaan itoelah soenggoeh loear biasa bagi Hidjo, boekan loear biasa kebagoesan pakaian orang-orang jang ada disitoe, tetapi loear biasa sebab itoe waktoe Hidjo bisa maemerentah orangorang Belanda, orang mana kalau di tanah Hindia kebanjakan sama besar kepala (Kartodikromo, 1919,p. 38-39).

Kutipan tersebut menunjukkan suatu upaya pengarang melalui perlawanan kultural atas perilaku penjajah kepada masyarakat Hindia. Hidjo mampu memerintah orang Belanda di negerinya sendiri. Hidjo menyadari bahwa sang penjajah di negeri asalnya tidak semua kalangan mempunyai watak ingin memerintah. Atas kontemplasi tersebut, ia berkesimpulan bahwa orang Hindia semestinya tidak diperintah oleh orang Belanda (Kartodikromo, 1919,p. 39).

Keinginan tersebut menggambarkan semangat perjuangan untuk menghapuskan penindasan, tuntutan persamaan antarbangsa, antara kaum Bumiputra dengan kolonial Belanda. Hal ini tergambar pada keinginan Walter untuk melamar Woengoe menjadi istrinya. Keinginan itu dijawab oleh ayah Woengoe, Regen Djarak dengan pernyataan berikut.

"Ach, perkara itoe toean," mendjawab Regent dengan merdika, "itoelah hanja tergantoeng orang jang mendjalani itoe assosiatie. Kalau boeat saja itoe perkara tjotjok sekali, karena sesoenggoehnja manoesia tidak ada bedanja, baik bangsa Boemi-poetra atau bangsa Belanda .. . bertjampoeran bangsa itoe bisa djadi baik, kalau bangsa satoe dan lainnja sama deradjatnja, sama kekoeatannja; sama kepertjajaannja... (Kartodikromo, 1919,p. $85)$.

Jawaban Regen Djarak tersebut menggambarkan kebijaksanaan seorang pemimpin yang tidak sombong akan jabatannya. Pemikirannya tentang hak asasi 
manusia tergambar dalam kutipan yang dicetak tebal di atas. Menurutnya, sebuah bangsa tidak berbeda, baik bangsa Bumiputra maupun bangsa Belanda. Bangsa yang satu dengan bangsa lainnya memiliki derajat yang sama meskipun akhirnya Walter tidak dapat diterima sebagai calon suami anaknya.

Merujuk pada deskripsi di atas, novel Student Hidjo merepresentasikan semangat keterdidikan perempuan dan wacana kesetaraan dalam segmen yang khas. Meskipun tokoh perempuan tidak mendapat porsi penuturan yang dominan, tokoh perempuan merupakan pihak yang diidamidamkan oleh laki-laki, seperti Hidjo kepada Woengoe, Wardojo kepada Biroe, dan Walter kepada Woengoe. Hal ini menempatkan perempuan sebagai objek karena kecantikannya. Akan tetapi, semangat untuk menimba pendidikan tergambar dalam sosok Biroe dan Woengoe sebagai representasi kaum priyayi Jawa yang mendapatkan kemudahan akses dalam menimba pendidikan.

Keduanya dihadirkan pengarang untuk menyadarkan pembaca bahwa pendidikan adalah sarana yang penting bagi Bumiputra. Terlepas dari ketimpangan sosial dan pertentangan kelas yang terjadi, pendidikan perempuan tetap diidealkan dalam novel Student Hidjo melalui bentuk formal dan nonformal (dalam arti nilai kearifan lokal tentang pemikiran perempuan). Konflik yang dibangun Mas Marco dengan wacana kesetaraannya itu ditempatkan melalui penyelesaian kisah yang manis. Di akhir cerita, perubahan rumus perjodohan menandai semangat perubahan pemikiran agar setiap manusia bebas menentukan kebaikan dan mendapat hak berpendapat.

Semua tokoh pemuda yang dihadirkan dalam kisah cinta kasih itu mendapat akhir yang bahagia. Hidjo menikah dengan Woengoe, Wardojo dengan Biroe, dan Walter dengan Betje. Peristiwa ini memperkuat akhir kisah yang menyuguhkan keinginan agar hidup bahagia tanpa penindasan dan penjajahan amat layak untuk diperjuangkan.

\section{2) Novel Hikayat Kadiroen (1922) karya Semaoen}

Seperti halnya Student Hidjo, novel Hikayat Kadiroen yang ditulis Semaoen menampilkan wacana kesetaraan secara dominan. Daya gedor Semaoen dalam menyuarakan keadilan dilancarkan melalui retorika yang khas dari tokoh Kadiroen. Hikayat sebagai judul menunjukkan bahwa pengarang menyuguhkan mutiara kehidupan dari sosok Kadireon, seorang pemuda keturunan lurah yang bijaksana.

Kadiroen dicitrakan sebagai sosok pemuda yang cerdas, kritis, dan peka terhadap ketidakadilan di sekitarnya. Ia merupakan sosok yang penuh prestasi, baik ketika sekolah maupun dalam pekerjaannya. Tugasnya sebagai seorang juru tulis, mantri polisi, asisten wedana, wedana, wakil patih dijalani secara gemilang. Ia tetap memihak kebenaran dalam setiap pekerjaannya dan tidak segansegan menumpas kejahatan. Kariernya pun melesat cepat.

Dalam prosesnya, ia bergabung dengan pergerakan di partai komunis dan menulis secara anonim di surat kabar. Kegiatan itu diasosiasikan pengarang untuk mengkritik feodalisme dan kolonialisme yang terjadi di Hindia Belanda. Cita-cita untuk memperbaiki nasib rakyat, khususnya golongan bawah yang semakin tertindas. Kadiroen mulai aktif menyokong partainya. Bantuan ini dilakukannya secara rahasia. Pekerjaan Kadiroen akhirnya terbongkar oleh atasannya. Dia harus memilih antara pekerjaan atau partainya. Akhirnya dia memilih memperjuangkan partainya untuk kebahagiaan rakyat.

Pengarang novel ini lebih menekankan keunggulan golongan bawah. Hal itu terlihat dari keberhasilan ayah Kadiroen yang terpilih menjadi lurah meskipun berasal dari golongan bawah. 
Yulianeta (2008) menganggap bahwa dalam novel ini terdapat motif pengembaraan untuk mendewasakan tokohnya. Hal ini tampak pada pengembaraan Kadiroen yang memulai petualangannya sebagai juru tulis, mantri polisi, sampai wakil patih. $\mathrm{Di}$ tengah pengembaraannya itu, ia bertemu dengan ketidakadilan, perampasan harta rakyat oleh pegawai yang korup, dan ketidaksolidan kaum Bumiputra (antara kaum priyayi dan golongan bawah).

Persoalan ini turut dihadirkan pengarang melalui peristiwa laporan pencurian yang mendapat respons yang berbeda dari Raden Pandji Koentjoro-NotoProdjo-Ningrat. Tokoh itu merupakan teman sekolah Kadiroen yang gila hormat dan suka memerintah. Gelar kebangsawanan membawa tokoh ini kepada jenjang kepemimpinan. Sifat kesewenang-wenangan terhadap yang lebih rendah dipertentangkan dengan sifat menjilat pada atasan. Tokoh ini menjadi lambang golongan atas yang tidak mempunyai kemampuan memimpin. Kebodohannya sudah terbukti sejak masih bersekolah. Dia tidak disukai, baik oleh gurunya maupun oleh teman-temannya (Semaoen, 1922,p. 12).

Raden Pandji dijadikan contoh pendidikan yang gagal. Raden Pandji sebagai kaum terpelajar dalam kehidupan sehariharinya tidak memperlihatkan sebagai seorang yang berpendidikan. Laporan pencurian yang berasal dari golongan yang berbeda ia tanggapi berbeda. Ia lebih memilih mengurusi laporan pencurian ayam milik Zoetsuiker (seorang penguasa perkebunan tebu) dibandingkan laporan rakyat biasa bernama Soeket yang kerbaunya hilang. Akhirnya, Kadiroenlah yang menangani kasus Soeket.

Dalam penyelesaian kasus itu, Raden Pandji gagal menemukan pencuri ayam Zoetsuiker karena menggunakan taktik "maling ditangkap dengan maling", sedangkan Kadiroen berhasil meringkus pencuri kerbau Soeket dan membongkar pencurian ayam Zoetsuiker. Atas strategi jebakan dan keberaniannya, Kadiroen mendapat hadiah berupa kenaikan pangkat dan Raden Pandji yang gagal menemukan pencuri mendapat teguran dari atasannya (Semaoen, 1922).

Peristiwa ini sejalan dengan ilustrasi kutipan berikut, "Begitoelah doea orang jang satoe sama lain berlainan sebagai siang dan malam mesti bekerdja ber-sama2, jang baik mendjadi Menteripolitie jang terperentah, dan jang boesoek mendjadi Aesistent wedono, jang memerentah (Semaoen, 1922,p. 12). Kontradiksi yang menarik bagi etos kerja seorang pemuda pribumi dengan karakter yang berbeda. Dalam momen tersebut, lagi-lagi Kadiroen direpresentasikan sebagai sosok heroik yang gagah berani dan cerdas.

Selanjutnya, di sela-sela tugasnya sebagai seorang pegawai pemerintahan, Kadiroen bertemu Ardinah yang menjadi selir lurah Kromo Kenggolo. Ardinah tetap mempertahankan idealismenya untuk menjaga kehormatannya. Ia berupaya melepaskan diri dari lurah tersebut. Ardinah juga berusaha membantu istri pertama lurah untuk mendapatkan haknya. Hal ini menunjukkan bahwa tokoh Ardinah merupakan sosok perempuan yang berupaya melawan ketidakadilan.

Kehadirannya tidak dijelaskan secara eksplisit oleh pengarang mengarah pada pendidikan formal seperti tokoh Kadiroen, cita-citanya menyuarakan kesetaraan menunjukkan bahwa dirinya simbol perempuan terdidik meskipun berasal dari keluarga miskin. Keadaan memperkuat dirinya menghayati pengajaran pentingnya hak-hak perempuan dalam kehidupan.

Ardinah memiliki semangat yang tinggi untuk mengusung keadilan untuk perempuan, khususnya masyarakat Jawa yang acapkali menjadi sasaran lelaki hidung belang semata. Meskipun menjadi selir lurah yang rakus, Ardinah berupaya sedemikian rupa untuk melindungi "kehormatannya". Secara tersirat, ia menginginkan tatanan masyarakat yang adil dan damai, tidak memandang kelas dan menghargai hak-hak manusia. Hal ini 
tampak disuarakannya melalui kutipan berikut.

“0, toeankoe! Apakah sebabnja saja poenja agama Islam memperkenankan orang laki berkawin lebih dari satoe, sedangnja biasanja itoe idinnja agama sering dibikin alasan sewenang-wenang oleh orang laki jang hanja soeka mainan sadja pada kita orang perempoean. Karena itoe, maka saja poenja golongan perempoean sering dapat tjelaka batin...Selamanja orang laki semoea beloem bisa baik dan adil, maka lebih baik kalau agama kita melarang perkawinan lebih dari satoe perempoean (Semaoen, 1922,p. 51-52).

Kutipan tersebut menggambarkan sosok perempuan yang berupaya melawan ketidakadilan dalam kehidupan. Ardinah memiliki kesadaran bahwa kaum perempuan sudah sepatutnya mendapatkan keadilan dan kebahagiaan yang hakiki. Ia mengkritik keadaan bahwa perempuan selalu ditempatkan inferior, sedangkan laki-laki menjadi pihak yang selalu diuntungkan dan lebih superior. Gagasan ini menyiratkan bahwa tokoh ini memiliki idealisme, daya kritis, dan kepekaan terhadap kaumnya.

Dalam novel Hikayat Kadiroen, Kadiroen dan Ardinah menjadi representasi kaum Bumiputra yang memiliki semangat yang sama dalam menegakkan keadilan dan perdamaian. Keduanya diceritakan menyimpan daya tarik masing-masing sehingga pada akhir cerita pengarang membuat keduanya bersatu. Hal itu ditempuh setelah kedua tokoh menjalani lika-liku kehidupan yang mendewasakan pemikirannya. Dengan demikian, hal ini memperkuat gagasan keterdidikan perempuan dan wacana kesetaraan sebagai bagian yang menarik dalam zaman pergerakan.

\section{3) Novel Rasa Merdika (1924) karya Mas Marco Kartodikromo}

Seperti halnya novel Student Hidjo dan Hikayat Kadiroen, novel Rasa Merdika (1924) dengan gigih menyuarakan wacana kesetaraan dan keterdidikan perempuan melalui narasi yang khas. Setelah bergabung dengan gerakan komunisme, Mas Marco Kartodikromo menampilkan wacana yang lebih garang melalui tokoh Soedjanmo-tokoh yang menjadi subjudul novel Rasa Merdika.

Seperti halnya sosok Hidjo yang berpendidikan dan cukup terpandang, tokoh Soedjanmo dibuat Mas Marco sebagai keturunan borjuis yang berkecimpung di dunia pemerintahan kolonial. Soedjanmo digambarkan sebagai pemuda yang baik budi, patuh, dan polos. Hal ini tampak deskripsi pengarang atas tokoh tersebut.

Soedjanmo, seorang pemoeda jang baik boedi, berbadan tegak serta sehat. Perkataannja senantiasa lemah lemboet, tetapi berhati keras. Setengah ta-hoen lamanja sesoedah Soedjanmo keloear dari sekolah beloemd pernah ia mendjabat pekerdjaan, hanja selamalamanja itoe menolong-nolong kepada pekerdjaan bapanja sahadja. bey Soemo, seorang asisstent wedono jang bertempat/ dalam onderdistrict jang soenji (Kartodikromo, 1924,p. 4).

Kutipan tersebut memperkuat karakteristik tokoh Soedjanmo sebagai manusia yang baik. Ia berada pada lingkungan pemerintahan yang korup seperti halnya dialami tokoh Kadiroen dalam Hikayat Kadiroen. Soedjanmo merasa tersiksaberkecimpung di dunia pegawai yang birokratis dan gila hormat. Soedjanmo berhenti dari pekerjaannya dan mencari pekerjaan yang sesuai dengan kehendaknya.

Dalam perjalanannya, Soedjanmo bertemu dengan Kromotjiloko-bekas petani yang hendak menjadi buruh di kota. Nama tokoh ini merupakan lambang manusia yang terus-menerus dirundung malapetaka (Yulianeta, 2008). Melalui perjumpaan inilah Soedjanmo memperoleh gambaran penderitaan petani-petani kecil yang tanahnya disewa dengan harga murah dan tidak memadai. Nasib Kromotjiloko membuatnya simpati. Hal ini menggugah kesadarannya bahwa telah terjadi ketidakadilan pada kelas 
buruh dan tani dalam struktur sosial yang ada.

Selanjutnya, pengarang mempertemukan Soedjanmo dengan Sastro di kota lain dalam perjalanannya bekerja pada sebuah firma dagang. Sastro merupakan seorang aktivis politik yang memasukkan ide perjuangan kepada Soedjanmo tentang kebenaran perjuangan kaum proletar. Tempaan lingkungan membuat kekritisannya semakin terbangun ketika Soedjanmo bertemu dengan Soepini, gadis yang giat dalam pergerakan politik.

Dalam peristiwa ini, Soepini merepresentasikan sosok perempuan yang terlibat dalam pembangunan untuk mengusung keadilan bagi rakyat jelata. Meskipun tidak secara eksplisit digambarkan pendidikan formal yang melatarbelakangi Soepini, tindakannya sebagai aktivis politik menunjukkan bahwa ia menjadi seorang perempuan terdidik. Selain itu, sosoknya menjadi unsur penguat wacana kesetaraan gender yang dibangun pengarang.

Gagasan ini menunjukkan bahwa perempuan memperoleh hak yang sama dalam kehidupan. Ia berhak untuk memperoleh pendidikan ataupun terlibat dalam aktivitas politik. Hal ini dibangun untuk meruntuhkan penindasan kaum bermodal kepada golongan proletar (buruh dan tani) yang mengalami berbagai penindasan. Yulianeta (2008) mengatakan bahwa penindasan dalam novel ini terjadi karena golongan bermodal terus-menerus memperkaya diri tanpa memperhatikan golongan lainnya. Bentuk penindasan tersebut ialah dengan cara menyewa tanah petani kecil dengan harga sewa yang rendah. Uang yang didapat petani itu tidak seimbang dengan keperluan hidupnya sehingga banyak petani yang beralih pekerjaan menjadi kuli di kotakota besar. Persoalan ini menggambarkan keberpihakan pengarang kepada golongan bawah yang mendapat perlakuan semenamena dari kepongahan penguasa.

Berdasarkan temuan ketiga novel di atas, ada titik tekan yang sama yang dilakukan kedua pengarang dalam novelnya. Keduanya sama-sama bernafaskan semangat pergerakan untuk mengusung masyarakat tanpa kelas. Konteks komunisme perlu ditempatkan sesuai konteks latar munculnya novel tersebut. Hal ini agar duduk persoalan tidak kabur dan dipandang sebelah mata seperti tindakan paranoid yang akhir-akhir ini menimpa bangsa kita.

Novel Student Hidjo (1919)dan Rasa Merdika (1924) karya Mas Marco Kartodikromo dan novel Hikayat Kadiroen (1922) karya Semaoen mengkritik kesewenang-wenangan pemerintah kolonial terhadap kaum Bumiputra. Selain itu, ketiga novel ini turut menggugah kesadaran masyarakat melalui bahasa yang dekat dengan rakyat, lokalitas dan kultur yang sangat sesuai dengan psiko-sosial masyarakat Hindia, terutama masyarakat Jawa.

Ganasnya pembangunan lambat laun menempatkan rakyat kecil atau golongan bawah semakin tersiksa, pertentangan kelas yang semakin menganga membuat masyarakat bersikap rasialisme dan etnosentrisme. Kemiskinan semakin memiskinkan hajat hidup rakyat, Fenomena inilah yang diangkat dalam ketiga novel tersebut.

Melalui novel, kedua pengarang menyuarakan realitas dunia yang diimpikannya. Ketiga novel sama-sama menghadirkan sosok pemuda yang berasal dari golongan menengah yang berupaya memperjuangkan persamaan kelas. Kehadiran Hidjo dalam Student Hidjo (1919), Kadiroen dalam Hikayat Kadiroen (1922), dan Soedjanmo dalam Rasa Merdika (1924) menyuguhkan narasi yang menarik tentang idealisme seorang pemuda. Ketiganya ditempa untuk menjadi manusia yang cerdas, kritis, dan peka terhadap kondisi bangsanya.

Hal itu tercapai melalui pengembaraan untuk mendewasakan pemikiran para tokoh. Setelah lulus sekolah HBS, Hidjo melanjurkan sekolahnya ke Belanda (tanah penjajahnya). 
Di sanalah ia mempelajari pentingnya keterdidikan dan kesetaraan untuk setiap bangsa. Sementara itu, Kadiroen mengalami pencerdasan melalui riwayat pekerjaannya, mulai dari juru tulis hingga wakil patih. Keberpihakannya pada keadilan rakyat golongan bawah semakin tajam ketika ia ikut dalam gerakan partai, terutama setelah bertemu dengan Tjitro. Ia menyuarakan keadilan melalui suplai dana dan menulis di surat kabar. Berbeda dengan Kadiroen yang kisahnya heroik, Soedjanmo dalam Rasa Merdika dicitrakan sebagai pemuda biasa yang belum tergugah untuk memperjuangkan keadilan. Hal itu lambat laun terkikis setelah ia mundur dari pekerjaannya dan mencari pekerjaan yang sesuai dengan kehendaknya.

Seperti halnya Kadiroen yang mendapatkan pencerdasan dalam masa pengembaraan, tokoh Soedjanmo mulai terbangun kekritisannya setelah bertemu dengan Kromotjiloko, Sastro, dan Soepini. Ia pun merasa perlu ikut andil dalam upaya pergerakan memperjuangkan keadilan dan kesetaraan bagi kaum Bumiputra, khususnya golongan bawah atau proletar.

Ketiga tokoh laki-laki yang menjadi tokoh utama dalam novel tampak ditunjang kehadirannya melalui aksentuasi perempuan yang sesuai karakteristik tertentu. Dalam novel Student Hidjo, tokoh Biroe dan Woengoe dihadirkan sebagai tokoh yang menunjang kesuksesan tokoh Hidjo. Keduanya berasal dari kelas bangsawan yang merasakan mudahnya akses pendidikan. Sementara itu, Ardinah merupakan sosok perempuan kritis yang ditempa menjadi perempuan terdidik melalui keadaan. Ardinah menjadi sosok yang serasi dengan semangat dan pemikiran Kadiroen. Semangat itu pula terlihat dalam sosok Soepini yang hadir sebagai aktivis politik. Meskipun tidak diceritakan secara eksplisit menjalin kisah cinta dengan Soedjanmo, Soepini menjadi tokoh yang penting dalam memperkuat keyakinan Soedjanmo untuk bergerak memperjuangkan hak-hak rakyat, khususnya dari kaum buruh.
Keterdidikan perempuan dan wacana kesetaraan menjadi persoalan yang sebenarnya telah disuarakan dalam novel-novel Indonesia pra-Balai Pustaka, khususnya dalam novel Student Hidjo, Hikayat Kadiroen, dan Rasa Merdika. Meskipun perempuan tidak dijadikan tokoh utama, penekanan pentingnya pendidikan dan tuntutan untuk memperoleh hak yang sama (kesetaraan) menjadi penguat gagasan bahwa ketiga novel sama-sama menekankan pentingnya keterdidikan dan kesetaraan bagi pembangunan sebuah bangsa. Gagasan ini relevan dengan persoalan kemerosotan pembangunan kita yang acapkali melalaikan perempuan dan kontribusinya dalam kehidupan. Hal ini berpotensi memajukan pemikiran kita dalam berbagai aspek kehidupan, terutama dalam dunia kritik sastra Indonesia yang memotivasi dan menginspirasi sebuah perubahan yang dimulai dari keterlibatan perempuan untuk memajukan peradaban bangsanya.

\section{SIMPULAN}

Berdasarkan hasil penelitian dapat disimpulkan bahwa keterdidikan perempuan dan wacana kesetaraan menjadi topik yang disuarakan dalam novel-novel Indonesia praBalai Pustaka. Novel Student Hidjo (1919), Hikayat Kadiroen (1922), dan Rasa Merdika (1924) merepresentasikan gagasan tersebut melalui retorika yang khas dan unik. Ketiga novel tersebut menghadirkan sosok laki-laki sebagai tokoh utama dan perempuan sebagai tokoh penunjang. Dalam Student Hidjo, tokoh Hidjo dicitrakan sebagai sosok yang pendiam, pembelajar, dan kuat terhadap adat istiadat, sedangkan dalam Hikayat Kadiron, pengarang menampilkan Kadiroen sebagai sosok heroik, tangkas dan gagah menumpas kesewenangwenangan. Sementara itu, tokoh Soedjanmo digambarkan dalam Rasa Merdika (1924) sebagai pemuda lugu yang ditempa keadaan menjadi lebih kritis dan kuat.

Pencerdasan yang diterima oleh Hidjo, Kadiroen, dan Soedjanmo diperoleh dari bangku sekolah, aktivitas pekerjaan, organisasi, pergerakan, dan keadaan 
lingkungan yang mengkhawatirkan. Kesadaran ketiganya terbangun setelah menghayati kehidupan yang penuh dengan ketidakadilan, keserakahan, dan ketertindasan. Hal ini memantik kesadaran ketiganya untuk memperjuangkan kesetaraan dalam berbagai bidang, seperti hak untuk memperoleh pendidikan, mendapatkan pengakuan yang sama sebagai manusia, dan merasakan perdamaian dalam kehidupan berbangsa dan bernegara. Gagasan itu diperkuat dengan kehadiran perempuan sebagai sosok penunjang yang penting. Meskipun mereka tidak dijadikan tokoh utama, Biroe dan Woengoe (dalam Student Hidjo, 1919), Ardinah (dalam Hikayat Kadiroen, 1922), dan Soepini (dalam Rasa Merdika, 1924) mampu menjadi agen perubahan yang menginspirasi tokoh utama. Hal ini justru menunjukkan kekuatan tersembunyi dalam diri perempuan yang digambarkan sebagai kaum inferior dari kaum laki-laki. Dalam beberapa aspek tertentu, tokoh-tokoh perempuan muda yang sadar akan pentingnya keterdidikan dan kesetaraan menjadi gagasan menarik dalam perjalanan novel propaganda. Oleh karena itu, penelitian ini diharapkan memberikan perspektif yang berbeda dalam dunia kritik sastra Indonesia sehingga karya sastra Indonesia menjadi refleksi yang kaya akan peradaban suatu masa.

\section{DAFTAR RUJUKAN}

Anwar, A. (2009). Genealogi Feminis: Dinamika Pemikiran Feminis dalam Novel Pengarang Perempuan Indonesia 1993-2005. Jakarta: Republika.

Artawan, I.G., \& Yasa, I.N. (2015). "Mimikri dan Stereotipe Kolonial terhadap Budak dalam Novel-Novel Balai Pustaka". Jurnal Ilmu Sosial dan Humaniora, 4 (1), 557-565.

Culler, J. (1983). On Deconstruction; Theory and Criticism after Structuralisme. London and Henley: Roudledge and Kegan Paul.

Damono, S.D. (2013). "Kesusastraan Indonesia Sebelum Kemerdekaan". Kalam vol. 25, 1-72.
Djajanegara, S. (2003). Kritik Sastra Feminis (Sebuah Pengantar). Jakarta: Gramedia Pustaka Utama.

Endraswara, S. (2013). Teori Kritik Sastra. Yogyakarta: CAPS.

Gandhi, M. (2002). Kaum Perempuan dan Ketidakadilan Sosial. Penerjemah: Siti Farida. Yogyakarta: Pustaka Pelajar.

Hellwig, T. (2007). Citra Kaum Perempuan di Hindia Belanda. Penerjemah: Rahmatika. Jakarta: Yayasan Obor Indonesia.

Kartikasari, D. (2014)."Pelarangan Buku-buku Karya Sastrawan Lekra Tahun 19651968". Avatara, 2 (3), 453-466.

Kartodikromo, M. M. (1919). Student Hidjo. Semarang: Masman dan Stroink.

Kartodikromo, M. M. (1924). Rasa Merdika. Semarang: Masman dan Stroink.

Kompas. (2017). "Pelibatan Perempuan Masih Kurang", edisi 1 Juni 2017.

Mahayana, M.S. (2010). "Perempuan dan Agama dalam Novel Indonesia". Jurnal Studi Gender E Anak. Yin Yang, 5 (1), 65-87.

Nurgiyantoro, B. (2013). Teori Pengpenelitian Fiksi. Yogyakarta: Gadjah Mada University Press.

Ratna, N.K. (2013). Teori, Metode, dan Teknike Penelitian Sastra. Yogyakarta: Pustaka Pelajar.

Ridwan, et al. (2016). "Pandangan Pramoedya terhadap Resistansi Perempuan dalam Novel Era Revolusi dan Reformasi". Jurnal Adabiyyat, 15 (1), 63-86.

Rutven, K.K. (1990). Feminist Literary Studies; An Introduction. Cambridge: Cambridge University Press.

Saputra, H. (2011). "Menyuarakan Kaum yang Terabaikan”. Literasi, 1 (1), 135-140.

Semaoen. (1922). Hikayat Kadiroen. Semarang: Kantor PKI.

Suryakusuma, J. (1991). "Konstruksi Sosial Seksualitas: Sebuah Pengantar Teoritis". Prisma, No.7, 3-14. 
Jurnal Pendidikan Bahasa dan Sastra, Volume 18, Nomor 1, April 2018, pp. 81-94

Sadli, S., \& Soemarti, P. (1995). "Identitas Gender dan Peranan Gender". Dalam T. O. Ihromi. Penelitian Wanita dalam Pembangunan (p.69-82). Jakarta: Yayasan Obor Indonesia.

Udasmoro, W. (2009). Pengantar Gender dalam Sastra. Yogyakarta: Universitas Gadjah Mada.

Wiyatmi. (2013). Menjadi Perempuan Terdidik:

Novel Indonesia dan Feminisme.

Yogyakarta: UNY Press.

Yasa, I.N. (2013).'Orientalisme, Perbudakan, dan Resistensi Pribumi Terhadap Kolonial dalam Novel-Novel Terbitan Balai Pustaka". Jumal Ilmu Sosial dan Humaniora, 2 (2), 249-257.

Yulianeta. (2008). "Cap Bacaan Liar Pada Novel Propaganda Politik: Telaah atas Student Hidjo,Hikayat Kadiroen, Rasa Merdika". Jurnal Pendidikan Bahasa dan Sastra,8(2),1-14. 